\title{
Oblique strain partitioning and transpression on an inverted rift: The Castilian Branch of the Iberian Chain
}

\author{
G. De Vicente ${ }^{a}$ ? , R. Vegas ${ }^{a}$, A. Muñoz-Martín \\ a, J.D. Van Wees b, A. Casas-Sáinz \\ Y. Sánchez-Moya ' , A. Arche d, J. López-Gómez \\ d, A. Olaiz a , J. Fernández-Lozano \\ ', A. Sopeña d,

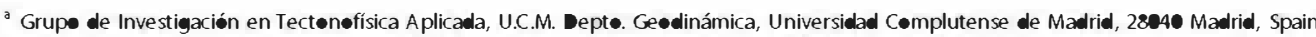 \\ - (6) TNO, Princetenlaan 6, 3584 CB Utrecht, The Netherlands

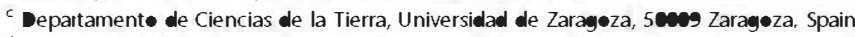

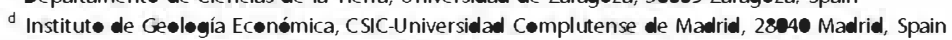 \\ e Departament• de Estratigrafía, Universidad C•mplutense de Madrid, 28040 Madrid, Spain \\ ${ }^{f}$ Faculty of Earth and Life Sciences, Vrije Universiteit, Amsterdam, The Netherlands
}

Keywerds:

Mesøic Rifting

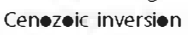

Transpressien

Iberia

\section{a b s t r a c t}

The Iberian Chain is a wide intraplate deformation zone formed by the tectenic inversion during the Pyrenean $\bullet \bullet$ geny $\bullet$ a Permian -Mesøzic basin develøped in the eastern part $\bullet$ f the Iberian Massif. The N-S

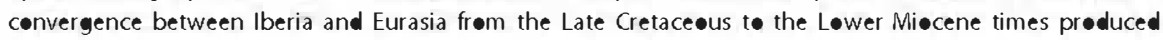
significant intraplate defermation. The NW -SE eriented Castilian Branch of the Iberian Chain can be

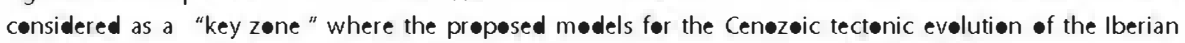
Chain can be tested. Structural style of basin inversion suggests mainly strike slip displacements along

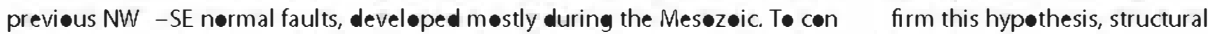

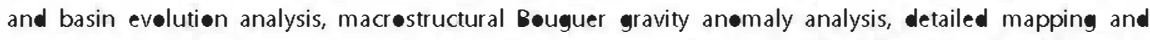

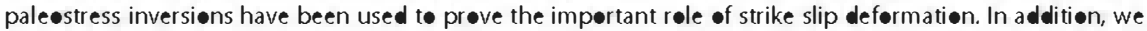

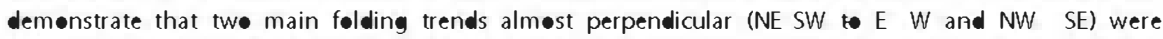

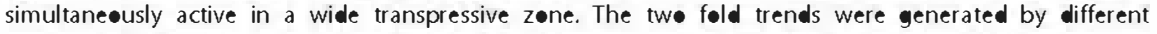
mechanical behaviøur, including buckling and bending under cønstrictive strain cønditiøns. We prøpese that

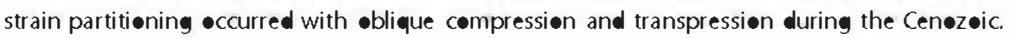

\section{Intreductiøn}

$\mathrm{N}-\mathrm{S}$ convergence between Iberia and Eurasia frøm the Paleecene

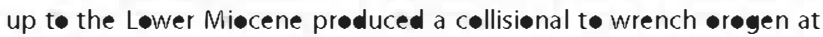
the northern berder of Iberia: The Pyrenees and the Cantabrian

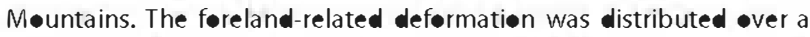
wide area that includes alsø the N•rth $\bullet$ Africa up to the Atlas Mountains( DeVicente and Vegas, in press ). It preduced a very regular

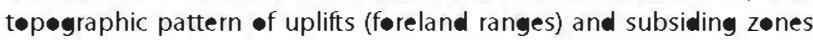
(føreland basins) that have been interpreted as lithøspheric følding (Cloetingh et al., 2002; Teixell et al., 2003 ) with Iberia mechanically

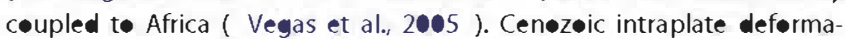
tiøns $\bullet$ Iberia left a deep imprint in the Iberian plate as they were able to invert pre-existing Mesøzic basins in eastern Iberia, such as the

\footnotetext{
? Correspending auther.

E-mail addresses: gdv@ge.ucm.es (G. De Vicente), ruidera@ge.ucm.es (R. Vegas),

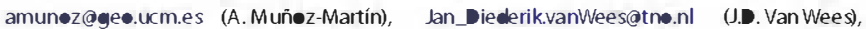

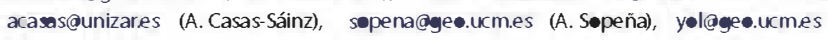

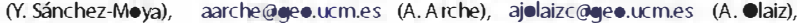

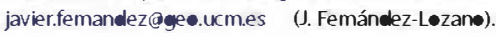

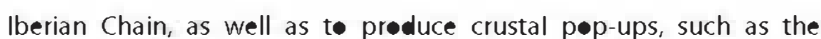
Central System, $\bullet$ ver the nøn extended central-western crust of Iberia (De Vicente et al., 2007a; De Vicente and Vegas, in press ,Fig. 1). Møst of the uplifted areas of the interior of the Iberian Microcontinent have been classically related the in fluence of the Betic $\bullet \bullet \cdot g e n y$, whereas the Iberian Chain has been cønsidered as the cønsequence of the Pyrenean $\bullet$ regeny with lower in fluence frøm the

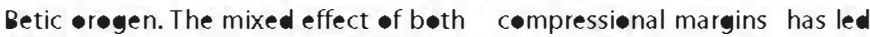
to multiphase evelutiønary models før the interiør of the Iberian Peninsula in general, and forthe Iberian Chain in particular ( Liesa and Simon-Gomez, 2007 ). These mødels, rather cømplicated within the plate-tectønic frame, have been mainly deduced frøm paleøstress analysis. In addition, an unusual pattern of superimp@sed følding that was probably in fluenced by pre-existing extensiønal structural geømetries has been attributed by Liesa (2000) and Capote et al. (2002) to subsequent changes in stress directiøns driven by def $\bullet$ rmation at plate margins.

An alternative structure-building and paleostress generation has been suggested in relation t• the Pyrenees and lithøspheric følds connected within the Upper Crust by strike -slip fault corriders for Western Iberia ( De Vicente and Vegas, in press ). Furthermere De 
Aragonese and Castilian Branches and the Altomira Unit (Guimerà, 2004 and references therein) (Fig. 1). The Iberian Chain is bounded to the $\mathrm{N}$ by the Cenozoic Ebro Basin, to the $\mathrm{W}$ by the Tagus Basin and towards the S, by the La Mancha Plain Basin. It also comprises several intra-mountainous basins, the Almazan Basin (The SE part of the Duero Basin) being the most important, the Calatayud and Montalban

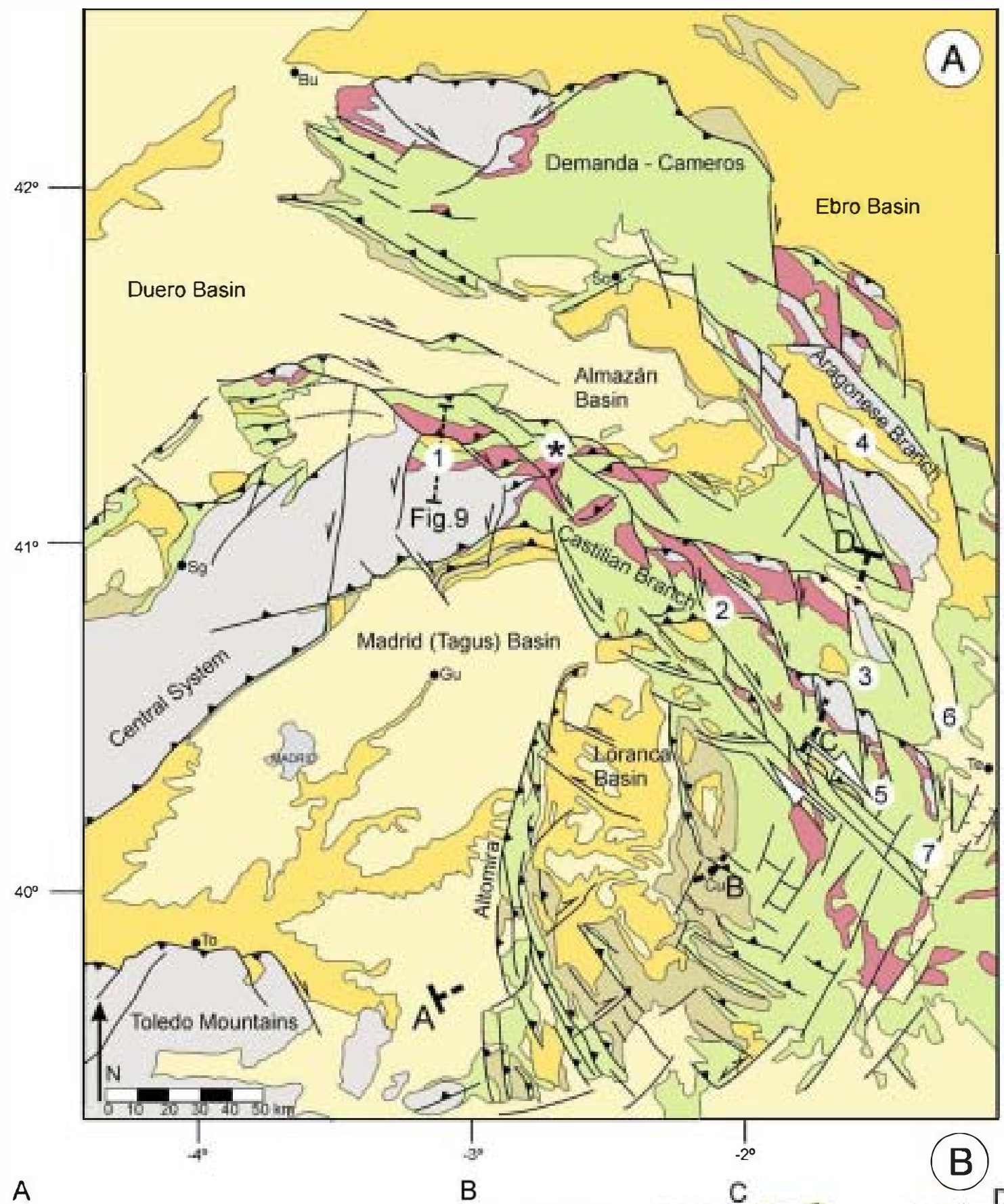

A

B

C D
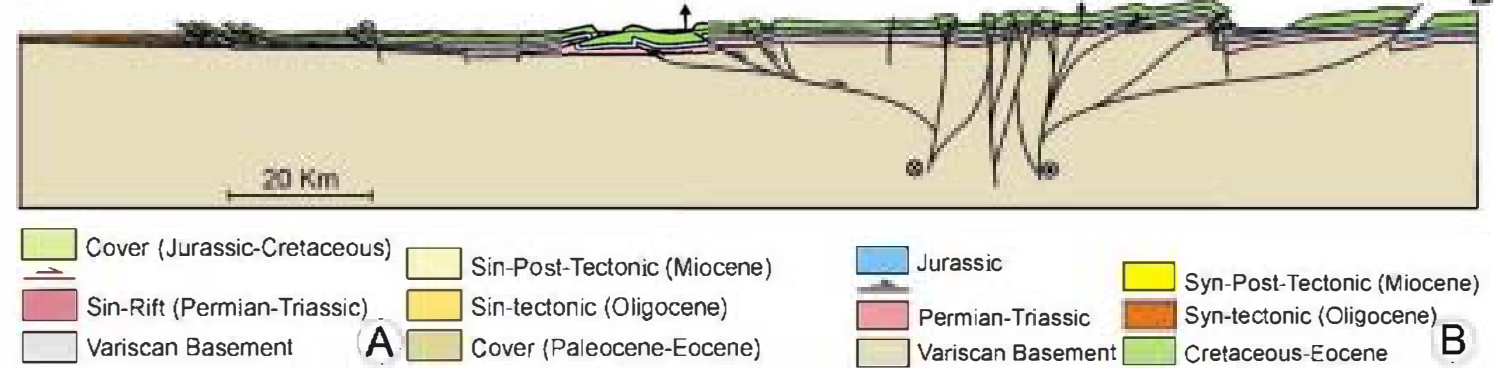

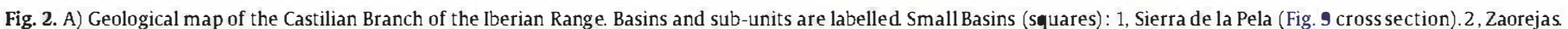

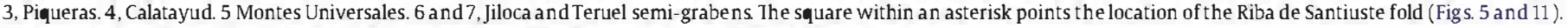
B) Cross section (showed in A), A-B-C-D) showing the positive flower structure of the Castilian Branch. 
basins and the Loranca Basin. The Almazan Basin separates the Aragonese and the Castilian Branches and has been interpreted as a piggy-back basin related to the thick-skin thrust of the Cameros Unit over the NW Ebro Basin. The Tagus Basin can be subdivided into two parts: The Madrid Basin towards the $W$ and the Loranca (intermediate) Basin to the $\mathrm{E}$ both separated by the Altomira Unit. The Loranca Basin is also a piggy-back basin, related to thin-skin tectonics.

During the opening of the Valencia Through (Miocene), the eastemmost part of the Iberian Chain was affected by an extensional episode whose most relevant structure is the NE-SW Teruel semigraben (Fig. 2 (7)). Except for those post-main-deformation extensions, all the contacts between the Chain and its surrounding basins are contractional folds and thrusts. Regarding the thrusting transport directions (towards the $\mathrm{N}$, the NE, the SE, the SW, the $\mathrm{W}$ and the NW) (Fig. 1), it is clear the double verging, "centrifugal”, general structure of the Iberian Chain (Salas and Guimerà, 1997; Guimerà et al., 2004). This can also be observed from the fold trend orientations, fold interferences and paleostress analysis (liesa and Simón-Gómez, 2007).

From a tectonic point of view, the Castilian sector of the Iberian Chain includes the NW-SE mountainous alignments between the Teruel semi-graben and the Central System (Fig. 2A) (Guimerà, 2004). Nevertheless, most of the stratrigraphic studies also consider, as a part of this unit, the westernmost sector of the Aragonese Branch (Sopeña, 2004). It is a relatively peneplained and elevated zone (average $1000 \mathrm{~m}$ ), where the main topographic steps are the result of the Quaternary fluvial erosion/incision, with the development of canyonlands-like morphology. The maximal heights are reached towards the SE (1856 m).

The Castilian Branch of the Iberian Chain shows a fan shape in map view, open to the East, with its width progressively increasing from NW (70 km along a NE-SW transect) towards the SE (200 km along a NE-SW transect). Thus, the northern limit with the Almazan Basin shows an ESE trend, whereas towards the south, the boundary between the Castilian Branch and the Madrid and Loranca Basins shows a SSE trend. The Castilian Branch is separated from the Aragonese Branch by the Almazan Basin, and both branches connect eastwards along the E-W, thick-skin Montalban thrust system (Northwards tectonic transport with a total Cenozoic shortening of 12-15 km.) (Casas et al., 2000; Guimerà, 2004) (Fig. 1). To the NW, the Castilian Branch terminates, in an almost perpendicular trend, against the Central System that constitutes an asymmetric NE-SW upper crustal pop-up (De Vicente et al., 2007a,b) (Figs.1 and 2). Towards the South and the West, it is connected with the Altomira Range, a N-S thin skin thrust system that has been explained as the result of tectonic escape towards the $W$ with an overall $N-S$ shortening (Muñoz-Martín et al., 1998).

The NW-SE main faults in the Castilian Branch have been related to thrusting (Guimerà, 2004) and perpendicular NE-SW paleostresses are ubiquitously interpreted throughout the Range (Liesa and Simon, 2007). Nevertheless, strike-slip movements have also been suggested as the main displacement component for these faults during the Cenozoic shortening (Rodríguez-Pascua and De Vicente, 1998). From the tectonic map of the Sierra de la Pela restraining bend (Fig. 2A (1)), it can be seen that the inversion of the Permian-Triassic rifting is along strike locally incomplete. This supports the idea of mainly strike-slip displacements along the ancient NW-SE normal faults. From this point of view, it is in this part of the Iberian Chain where the most important Cenozoic strike-slip tectonics was developed (Fig. 2B).

\section{Permian-Mesozoic rifting}

The geometry of the Permian-Triassic rifting and Iberian Basin development determined the orientation of the NW-SE Cenozoic structures of the Castilian and the Aragonese branches. From accurate
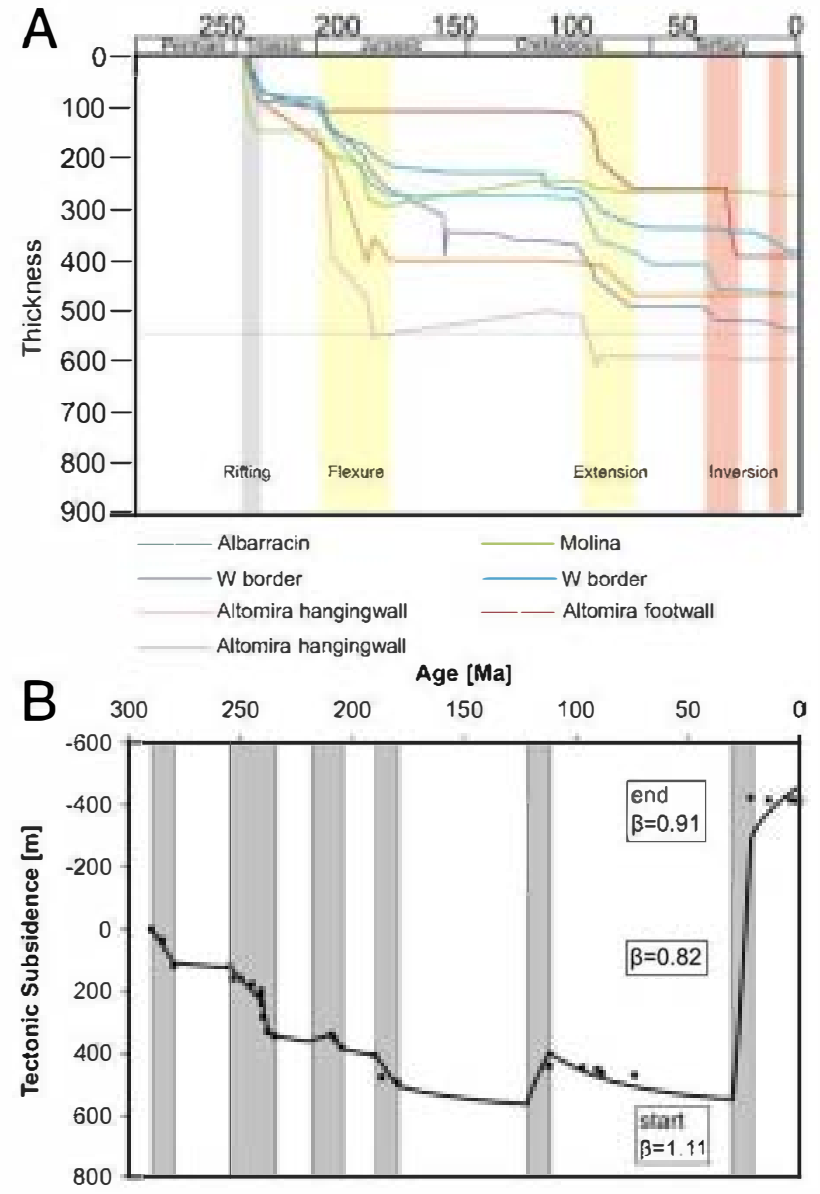

Fig. 3. A) Backstripping analysis of the Mesozoic infilling of the Iberian Basin in selected localities of the Castilian Branch. See Ramos et al (1996) and Van Wees et al (1998) for details. B) Backstripped tectonic subsidence ( $)$ of stratigraphic section I-3 (Van Wees et al, 1998), taking into account formation of $1000 \mathrm{~m}$ of topography during the inversion phase during the Oligocene, indicated by dark shaded box Line represents forward modelled tectonic subsidence, marked by polyphase extension (cf Van Wees et al, 1998). Prior to inversion, cumulative basin extension is marked by a stretching factor $\boldsymbol{\beta}=1.11$. Inversion is marked by $\boldsymbol{\beta}=0.82$, equivalent to ca $20 \%$ shortening and resulting in a cumulative crustal extension of $\boldsymbol{\beta}=0.91$, indicative of ca $3 \mathrm{~km}$ of crustal thickening underneath the Iberian chain.

backstripping analysis (Ramos et al., 1996; Van Wees, et al., 1998), it is concluded that the Permian-Mesozoic Iberian Basin evolution was marked by a number of extensional (rifting) pulses (Fig. 3A, B).

The rift pulses and related thermal uplift phases are of low magnitude, very short-lived and can be remarkably well correlated throughout the basin. The most important rifting episodes occurred during the Late Permian, Early Triassic, Early Jurassic and the Late Cretaceous (256-254 Ma, 245-235 Ma, 209.5-205 Ma, 190-180 Ma, 155-150 Ma, 97-88.5). Nevertheless, during the Early Permian (290$270 \mathrm{Ma}$ ) stretching appears to be localised, whereas during the Early Cretaceous (146-112 Ma) stretching is very differentiated and diachronous, resulting in local extension rather than in a single stretching phase. The total amount of stretching and associated crustal deformations during this stage are low, in agreement with the intraplate setting of the Iberian Basin (Van Wees et al., 1998).

The Permian basins follow zones local zones although suffering intense subsidence, probably indicating a relationship with strike-slip tectonics. These would originate in releasing bends and/or pull-apart basins, taking into account that relevant late Variscan strike-slip faults are also associated with andesitic volcanism (Fig. 4A). The 


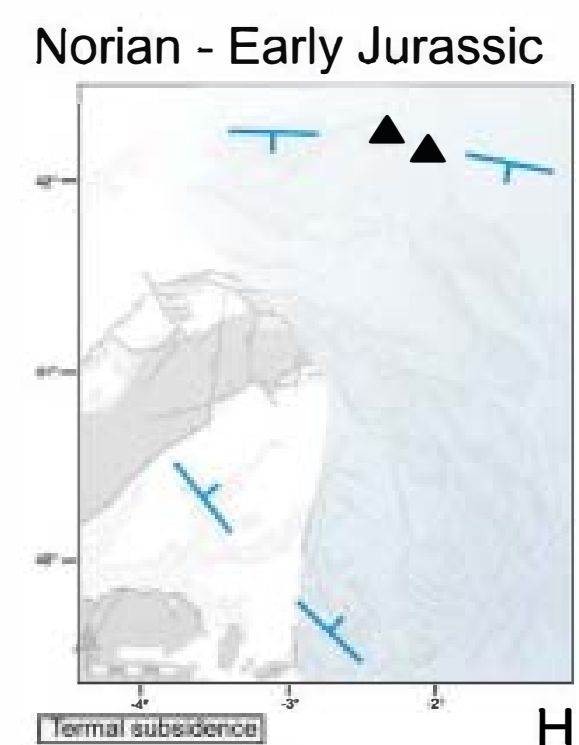

\section{Early Asinian}

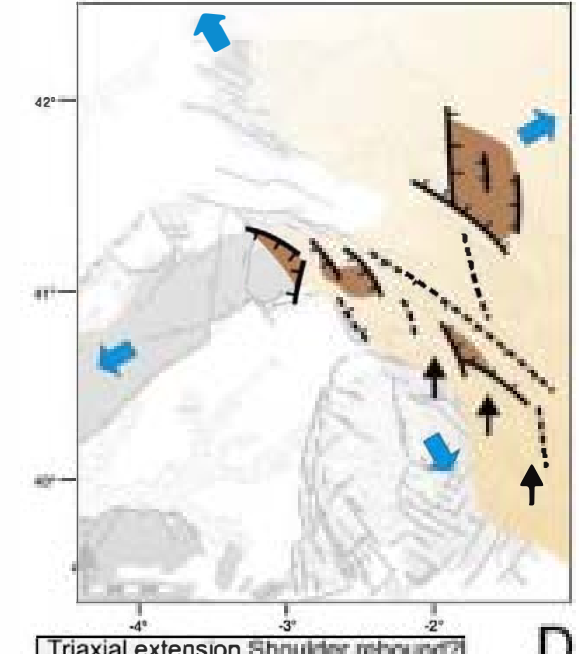

Carnian

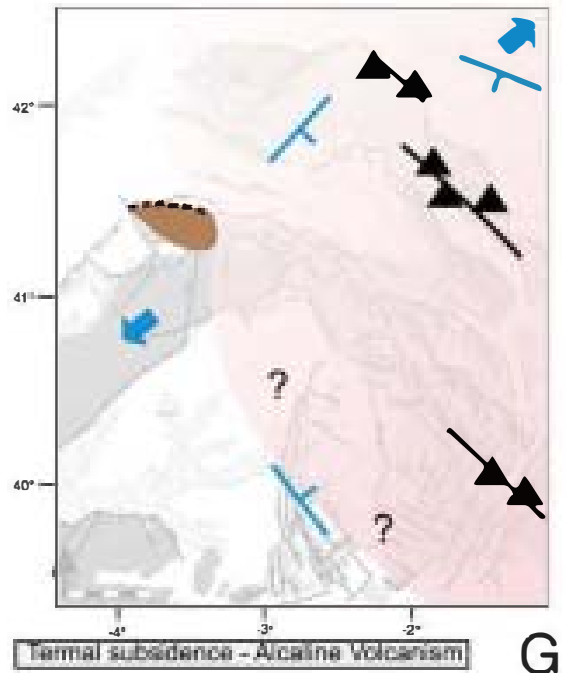

Scythiense

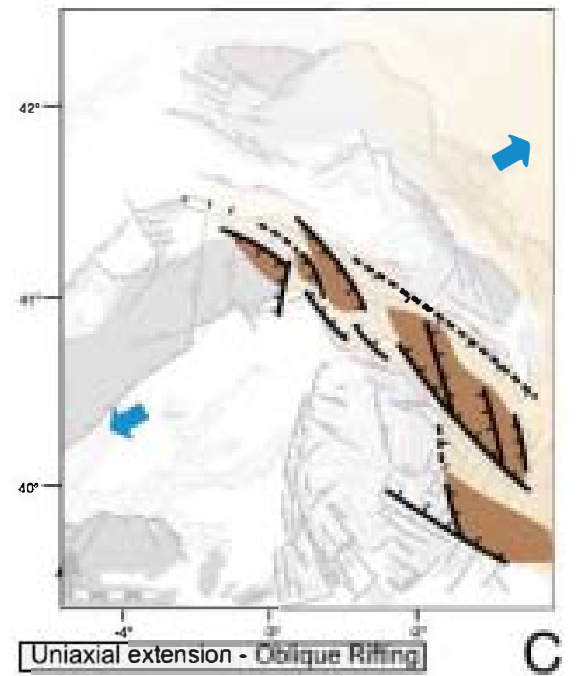

Ladinian

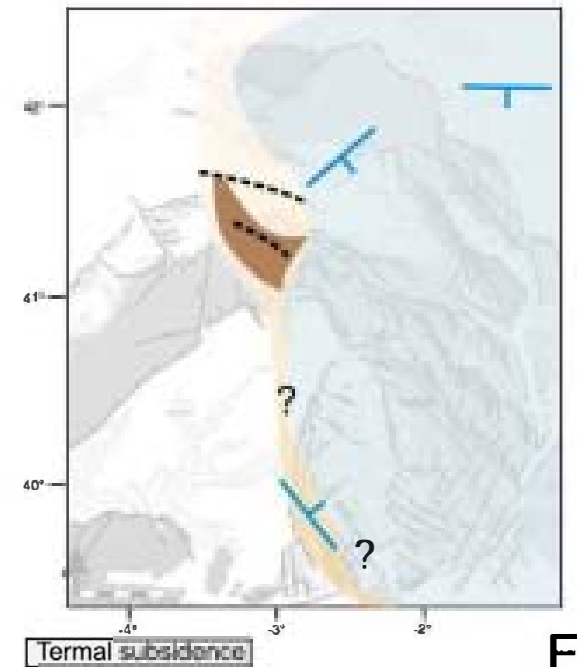

Late Permian

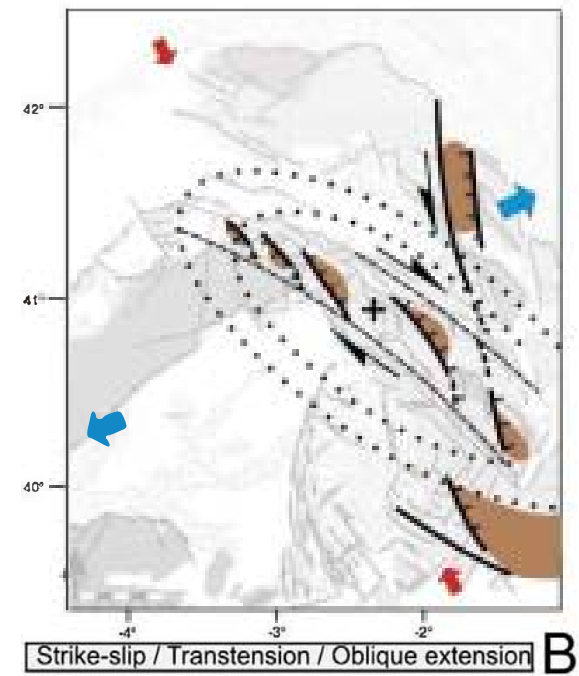

Late Asinian

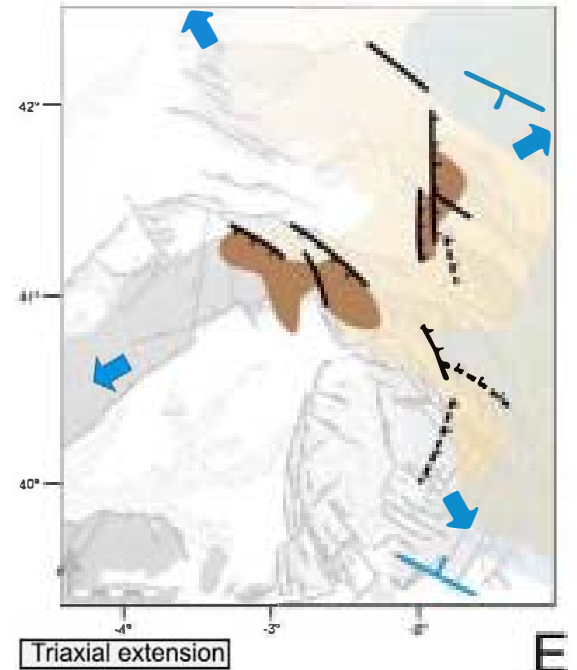

\section{Early Permian}

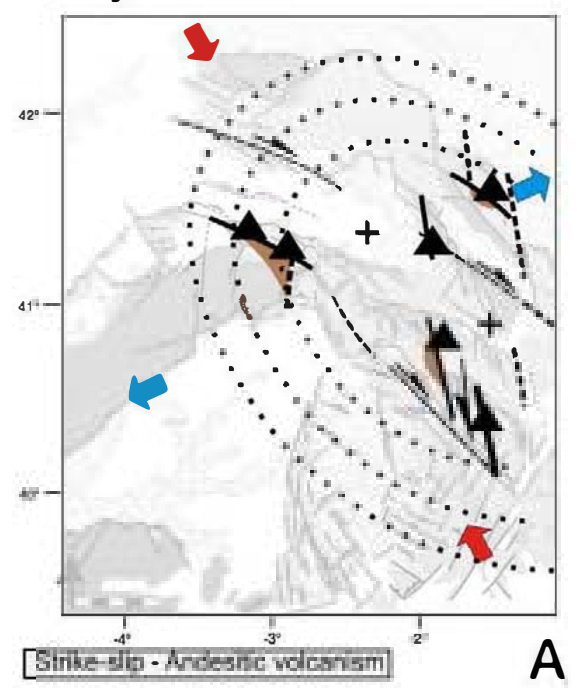

\begin{tabular}{|c|c|c|}
\hline No Sedimentation & Compression & Tectonic backyround \\
\hline Fluvial deposits & Extension & 7 Tilting \\
\hline Main depocenters & Normal fault & Local uplift \\
\hline Mari-Clay-Gypsum & Strike-slip fault & Vulcanism \\
\hline Limestones & Gen & \\
\hline
\end{tabular}


sedimentary record of the Late Permian and Early Triassic shows four major, sudden, vertical changes in fluvial style. These changes have been explained by both intrabasinal factors and tectonic events. Specially, alluvial fan systems perpendicular to the main faults can be related to extensional pulses creating high relief areas in the footwall blocks of normal faults, while vertical transition to fluvial networks parallel to the basin axis have been explained by the growth of graben structures during syn-rift stages (Ramos et al., 1986; Arche and LópezGomez, 1996; Arche et al., 2004).

Related geometries are half-graben with roll-over anticlines, as can be reconstructed from the mapping of the NE-SW Cenozoic folds (Fig. SA), especially on vertical flanks as in the Riba de Santiuste SE verging fold (Sanchez-Moya, 1991; Sanchez-Moya et al., 1996) (asterisk in Figs. 2 and 5B). However, it is from the analysis of the isopachs of the Lower Triassic (Buntsandstein red bed facies) that the geometry of the normal faults associated with the immediately subsequent period of rifting can be reconstructed (Fig. 6A). Some main faults (not linear) controlling the Permian-Triassic infilling: the Serrania de Cuenca Fault and the Molina-Teruel-Espadan Fault have been defined (Arche and López-Gomez, 1996). However, the correlation between thickness changes and faults now visible on the geological mapping is not evident (Figs. 4 and 6A), and we prefer to use unequivocal fault names to refer to these main faults. From this perspective, the Somolinos Fault System (Serrania de Cuenca Fault?) would be the most important western structure of the Triassic Rift (rift boundary) (Sopeña, 1979; Sanchez-Moya et al, 1996) (Figs. 4B and 6A). However, the overall geometry of the Triassic rift corresponds rather to a zone in which the extension is distributed in many faults, and appears hardly concentrated along individualized, long grabens, as deduced from the infilling history (Fig. 4B-E). This feature may point out to a high degree of mechanical coupling between the brittle and viscous levels of the lithosphere, characteristic of an aborted rift. The orientation of the active faults during this period is N140E (as is the Somolinos Fault, Fig. 6A), but it is also N170E (As suggested also by Arche and LópezGomez, 1996) and NE-SW, which results in horst rhomboids producing stratigraphic highs. These orientations of simultaneously active normal faults probably indicate extension under triaxial conditions, rather than successive extensional phases, and roughly respond to a $S_{\text {hmin }}$ located in a NE-SW direction (Figs. 4 and 6A).

From observations of the variations of thickness of the Triassic sedimentary infilling of the Iberian Basin, the basin margin faults have been interpreted as listric faults, originated as a response to dextral strike-slip movements at the margins of the Iberian Microplate and crustal collapse of the overthickened roots of the variscan orogen, rather than mantle plume-related processes (Arche and LópezGomez, 1996). From analogue modelling of wide rift-type structures it is observed that the maximum coupling between brittle and ductile layers, leading to homogeneous tilted block patterns, is obtained with the highest strain rates. For decreasing values of strain rates and brittle-ductile coupling, faulting becomes more symmetrical, leading to horst and graben patterns (Tirel et al., 2006). In models, the development of structures mainly depends on boundary conditions as velocity and therefore on bulk strain rate. Wide rifts are of tilted blocktype at high strain rate and of horst-and-graben type at low strain rate. Therefore, from the inspection of the sedimentary infilling history, shown in Fig. 4, it can be deduced that the Iberian Triassic extension probably created a wide rifting zone with a low strain rate.

Nevertheless, within the frame of weak related volcanism, in the central part of the rifting zone, intrusion of dolerite sills are registered as the expression of an alkaline magmatism. Since they are locally emplaced in gypsum-shale series belonging to the Keuper facies, they must be at least pre-Hettangian (Early Jurassic?) in age (Iago et al., 2004) (Fig. 4G, E, H). The alkaline composition of this magmatism is close to that of the OIB type. Crust-derived xenoliths (metapelites and granitoids) are common in these sills, suggesting that magma ascent took place through the rifting normal faults, that cut across different levels of the crust (Lago et al., 2002). The timing of alkaline magmatism was delayed from the main extensional pulse by about 40 Ma which agrees well with findings from other (aborted) rifts (Ziegler and Cloetingh, 2004).

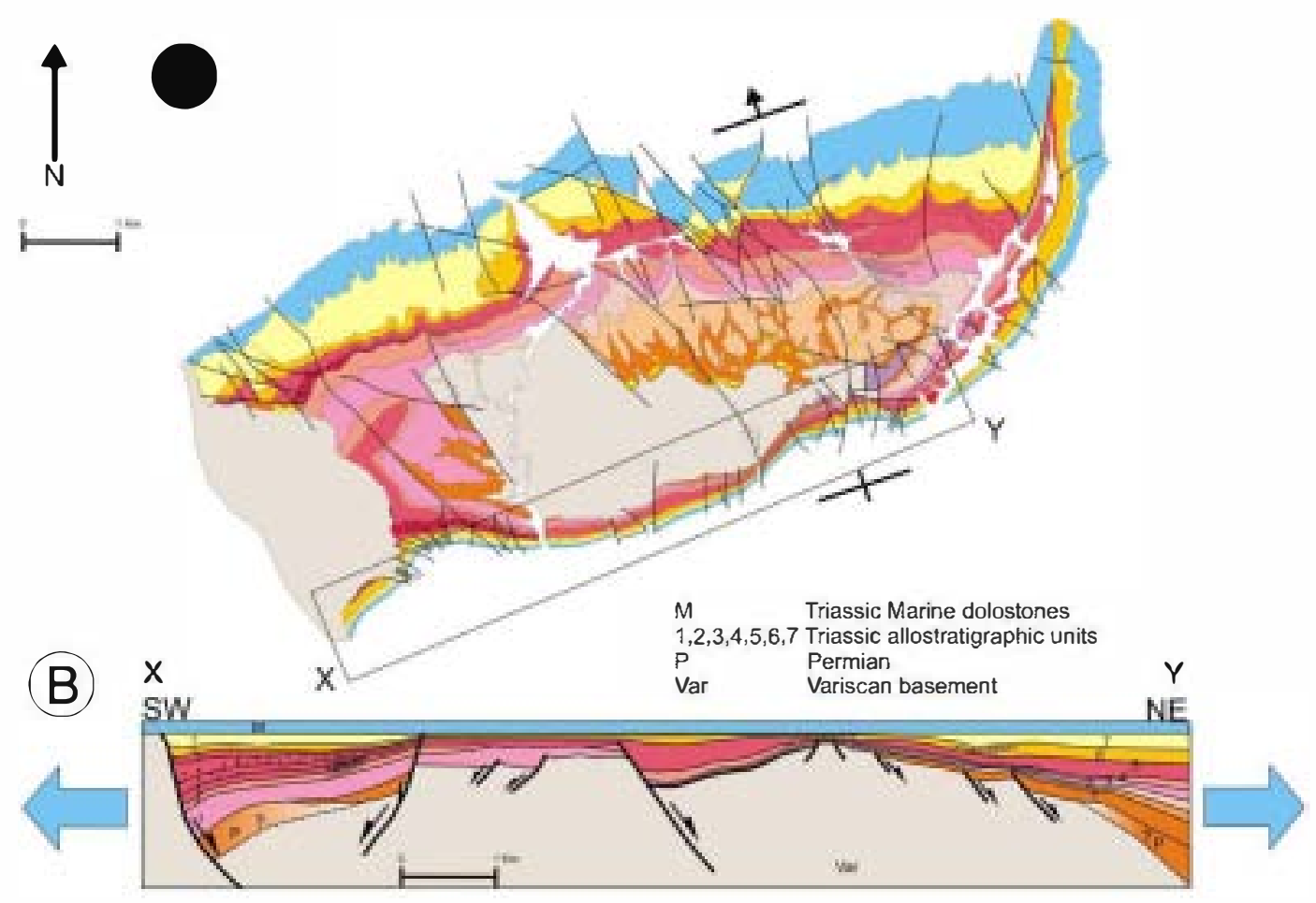

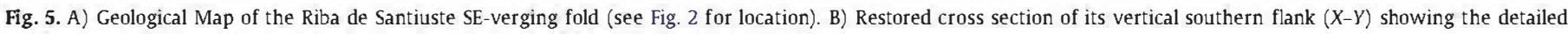
architecture and deformation style of the Permian to Triassic Rifting (Sánchez-Moya, 1991). 

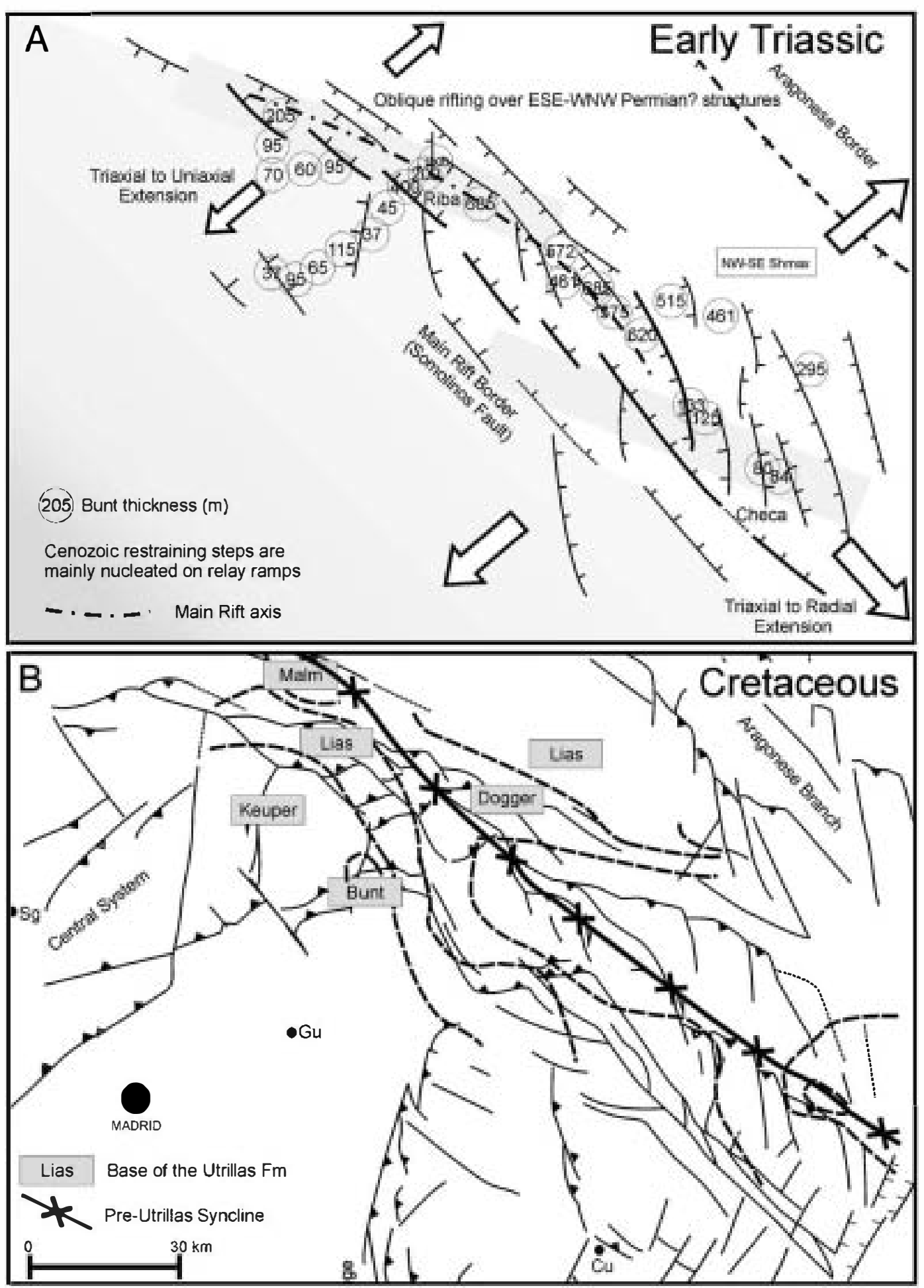

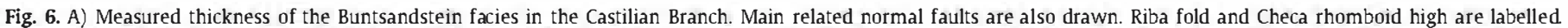

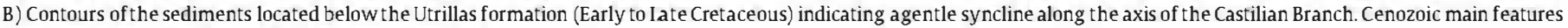
are also shown as a reference for both maps (see Fig. 2).

Finally, the whole area was under a general transgression during the Jurassic (Fig. 4H), indicating that no rift shoulder uplift occurred. This means that after rifting the paleo-Moho reached a relative low depth, and a not much depressed zone developed with the result subsequent flexural rebound (flexural subsidence) (Van Wees and Cloetingh, 1996).

The Early Cretaceous extensional stage, very important in surrounding areas of the Iberian Chain (Casas-Sainz and Gil-Imaz, 1998), did not create major structures in the Castilian Branch, except for a gentle NWSE syncline below the base of the Albian-Cenomanian Utrillas Formation (Fig. 6B).

Backstripping analysis indicates a very general subsidence of about $100 \mathrm{~m}$ along the Castilian Branch during the Iate Cretaceous (Fig. 3), but from more detailed mapping it is possible to observe gentle NWSE folding along the future Cenozoic Alto Tajo Fault System (Fig. 14), specially in the Montes Universales zone (Fig. 7A, B). Early Cretaceous 

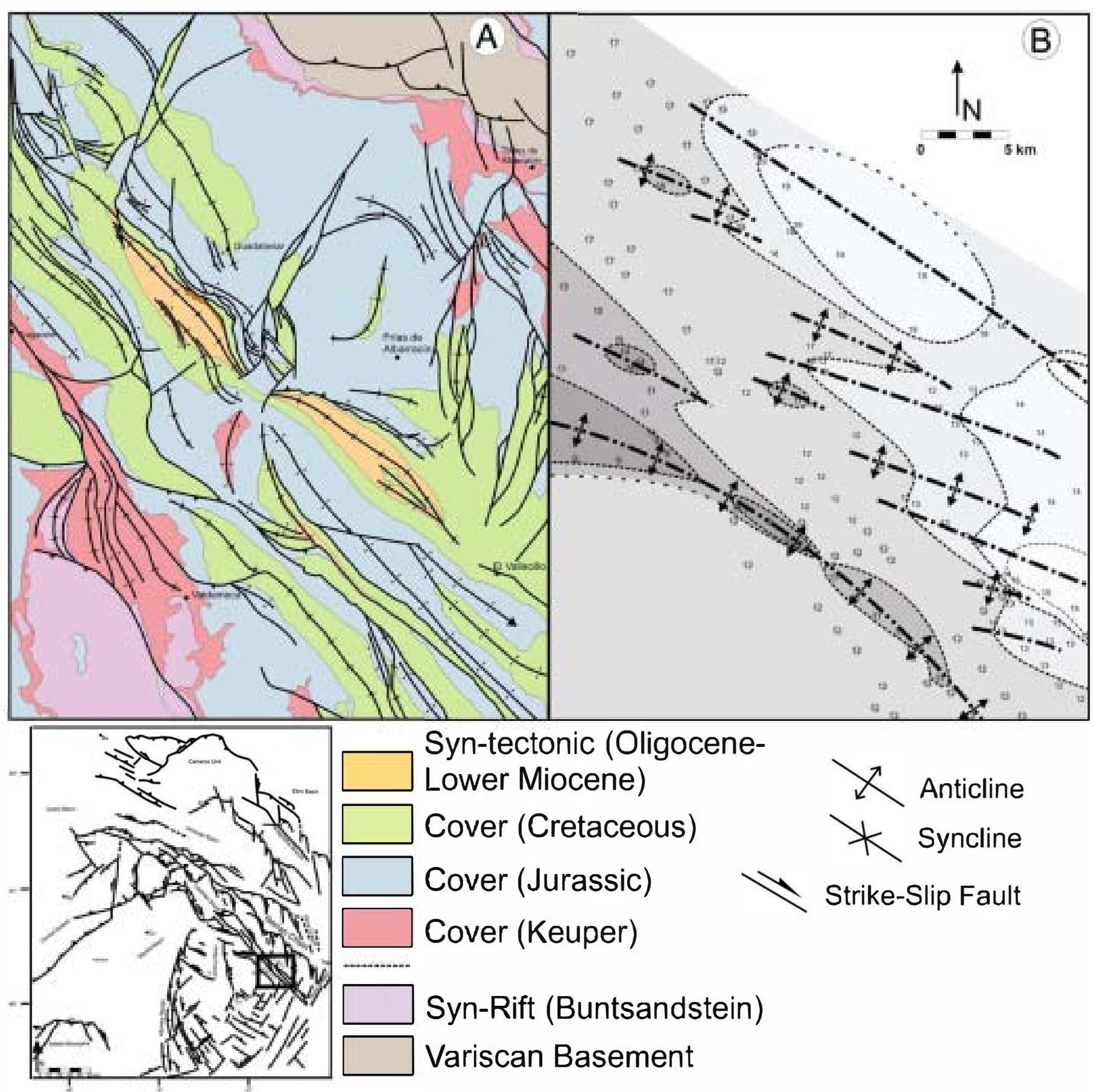

\section{Syn-tectonic (Oligocene- Lower Miocene) Cover (Cretaceous) Cover (Jurassic) Cover (Keuper)}

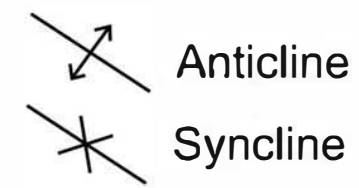

Strike-Slip Fault

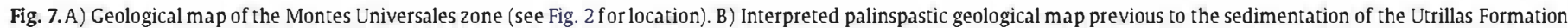
(Middle-Late Cretaceous). NW-SE to WNW-ESE folds can be inferred

sedimentation (Weald facies) is absent in the NW zone of the Castilian Branch and the Central System. In this last mentioned range, the main normal faults also bound an uplifted zone. This is the first Mesozoic sedimentary record showing tectonic activity prior to Cenozoic thrusting in the Central System. This arrangement seems to indicate some kind of weak re-activation of the NW-SE Triassic fault system during the Early Cretaceous intraplate extension.

4. Cenozoic inversion: Gravimetric constraints to the overall structure of the Iberian Chain

During the Cenozoic, the previously thinned crust of the Iberian Basin was thickened to build up the Iberian Chain. At present, all the
Iberian Range area shows a mean elevation close to one thousand meters above sea level in average, forming a part of the so called Iberian "Meseta", and probably in part related to Late TertiaryQuaternary isostatic uplift. Modelling of the Bouguer gravity anomaly is commonly used for Moho depth determination and, to some extent, shows the upper crust structure. Although gravimetric interpretation is not unique, it can help to validate proposed models based on geological constraints. In the Iberian Chain, the Bouguer gravity anomaly reaches minimum values of $-108 \mathrm{mGal}$, delimiting, together with the Central System, the absolute minima within the Iberian plate (Muñoz-Martín et al., 2004). In map view, the negative Bouguer anomaly linked to the Iberian Chain widens southeastwards and becomes narrower towards the North, where it divides into a series of 
relative maxima and minima oriented in NW-SE direction, parallel to geological structures (Fig. 8A, B). The relative maxima of the Bouguer anomaly in the Iberian Chain are linked to uplifts of the Paleozoic basement, in areas where it actually crops out (Moncayo Massif, Aragonese Branch; Fig. 2) or lies shallower (Castilian Branch). Gravimetric minima are mainly placed at the boundaries between the Iberian Chain and the Tagus and Almazan basins, where Tertiary sediments reach depths of more than 2000 mbsl.

To Interpret the overall deep crustal structure of the Iberian Chain from gravity modelling, a $280 \mathrm{~km}-\mathrm{long}$, NE-SW oriented crosssection was drawn, according to gravimetric constraints, using equally spaced gravimetric data every $5 \mathrm{~km}$, obtained from a $4 \mathrm{~km}$ spaced regular grid (Muñoz-Martín et al., 2004; Fig. 8B). This transect cuts across the main units of the Iberian Chain, called the Tagus Basin, the Castilian Branch, the Almazán Basin, the Aragonese Branch and finally the Ebro Basin. Along this profile, the main features of the Bouguer gravity anomaly are: i) a $200 \mathrm{~km}$-wide low, centered in the Iberian Chain, with a maximum amplitude of 25$30 \mathrm{mGal}$; ii) two 60 to $80 \mathrm{~km}$-wide highs in the Bouguer gravity anomaly, with amplitudes of 15-20 mGal, superimposed on the latter mentioned anomaly, and coinciding with the two main branches (Aragonese and Castilian) of the Iberian Chain; iii) three short-wavelength maxima (20-30 km wide) with amplitudes of $10-$ $15 \mathrm{mGal}$, placed over the Paleozoic basement uplifts (Fig. 8C).

In order to model the Bouguer gravity anomaly in the Iberian Chain, the density log was simplified and only six different densities
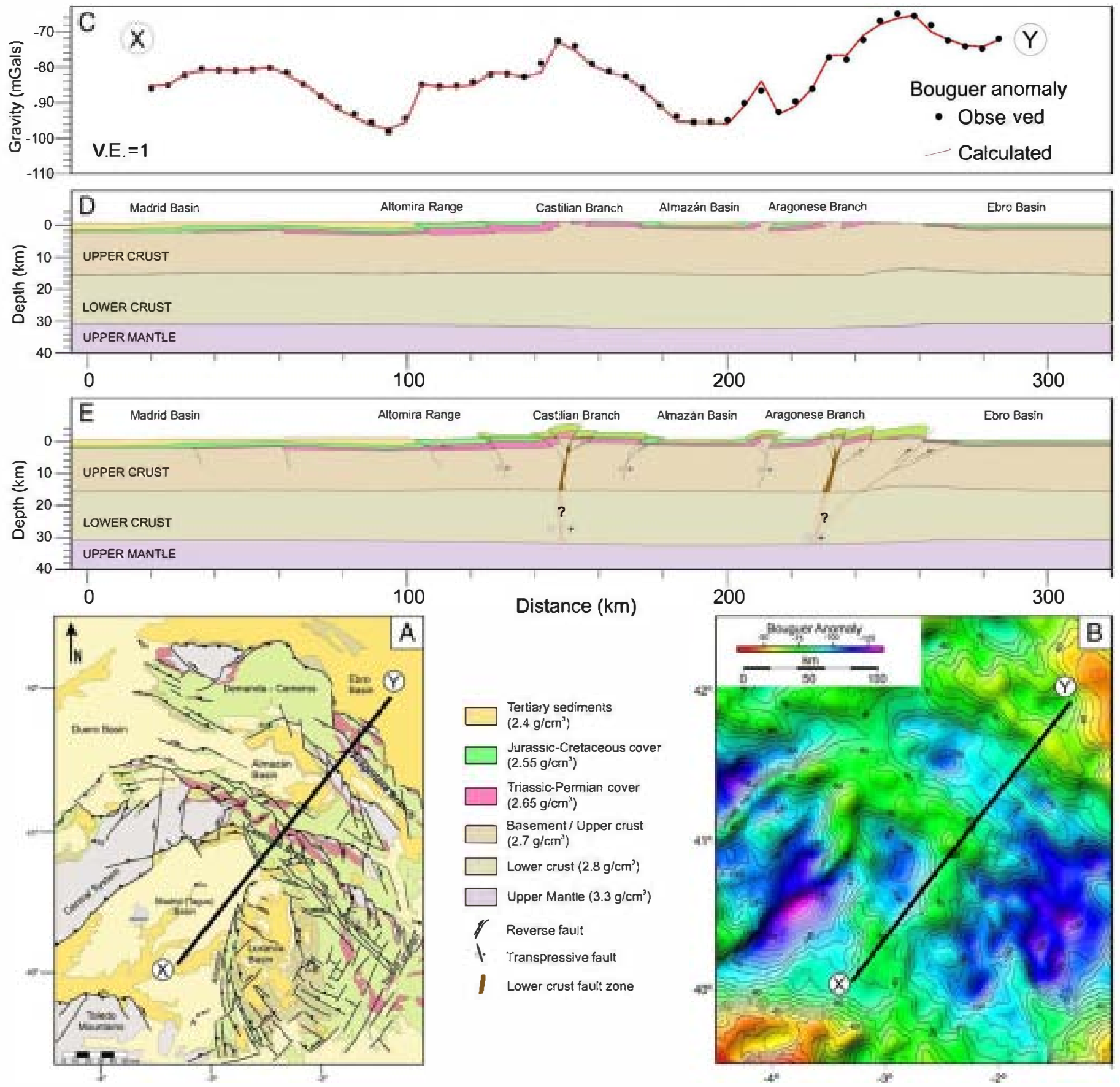

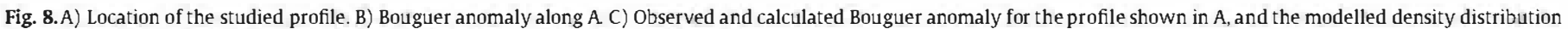
shown in D. D) Fitted model of density distribution E) Tectonic interpretation of D. 
Table 1

Density log simplified for six different existing rock types (Fig. 8D).

\begin{tabular}{ll}
\hline Tertiary sediments & $2.4 \mathrm{~g} / \mathrm{cm}^{3}$ \\
Jurassic-Cretaceous cover & $2.55 \mathrm{~g} / \mathrm{cm}^{3}$ \\
Triassic-Permian cover & $2.65 \mathrm{~g} / \mathrm{cm}^{3}$ \\
Variscan Basement & \\
Upper crust & $2.7 \mathrm{~g} / \mathrm{cm}^{3}$ \\
Lower crust & $2.8 \mathrm{~g} / \mathrm{cm}^{3}$ \\
Lithosphere mantle & $3.3 \mathrm{~g} / \mathrm{cm}^{3}$ \\
\hline
\end{tabular}

were considered to represent the main existing rock types (Table 1, Fig. 8D). Density values were obtained from previous studies using experimental data (Campos, 1986; Rey-Moral et al., 2004) and from correlation with seismic velocities (Suriñach and Vegas, 1988; Querol, 1989). The thickness of Tertiary and Mesozoic units in the main terrestrial basins (Ebro, Almazán and Tagus) is well constrained from seismic reflection surveys, and the depth to the Moho at the two ends of the cross-section was obtained from the ESCI and IBERSEIS projects data (Pulgar et al., 1996; Simancas et al., 2003). Fitting of the calculated to the observed curves was done considering (i) in first instance the long-wavelength anomalies controlled by the depth to the Moho and then (ii) constraining the thickness of Mesozoic units and the geometry of the limits between the Paleozoic basement and the Mesozoic and Tertiary basins.
The results of gravimetric modelling indicate a gentle, symmetric crustal thickening with Moho depth $32 \mathrm{~km}$ below the Almazán basin, thus allowing for the minimum values of the Bouguer anomaly to be interpreted. The two relative maxima 60 to $80 \mathrm{~km}$ wide show differential features: the maximum located above the Castilian Branch is nearly symmetric and can be explained by means of uplifted basement blocks. Accordingly to its symmetric geometry and the strong gradient of the anomaly, both contacts of the Castilian Branch (with the Tagus Basin to the Southwest and the Almazán Basin to the North) were interpreted to be compressional in the cross-section. The gravity maximum located over the Aragonese Branch is asymmetric toward the NE, fitting with a northeast-verging thrust toward the Ebro Basin in the linking zone with the Cameros-Demanda Unit. The three shortwavelength relative maxima superimposed on the main anomaly are interpreted as a positive flower structure in the Castilian Branch and an asymmetric, NE-verging flower structure in the Aragonese Branch, along with there is a gradual thickening of the Cretaceous units towards the NE.

The density model obtained fits reasonably well with the observed gravity profile, with a cumulated error lower than $0.9 \mathrm{mGal}$, indicating a heterogeneously thinned (during the Mesozoic extensional stage) upper crust, because the thickness of the Mesozoic cover is considerably lower below the Tertiary basins than in areas with Mesozoic outcrops (inverted basins). This thinned crust underwent a subsequent
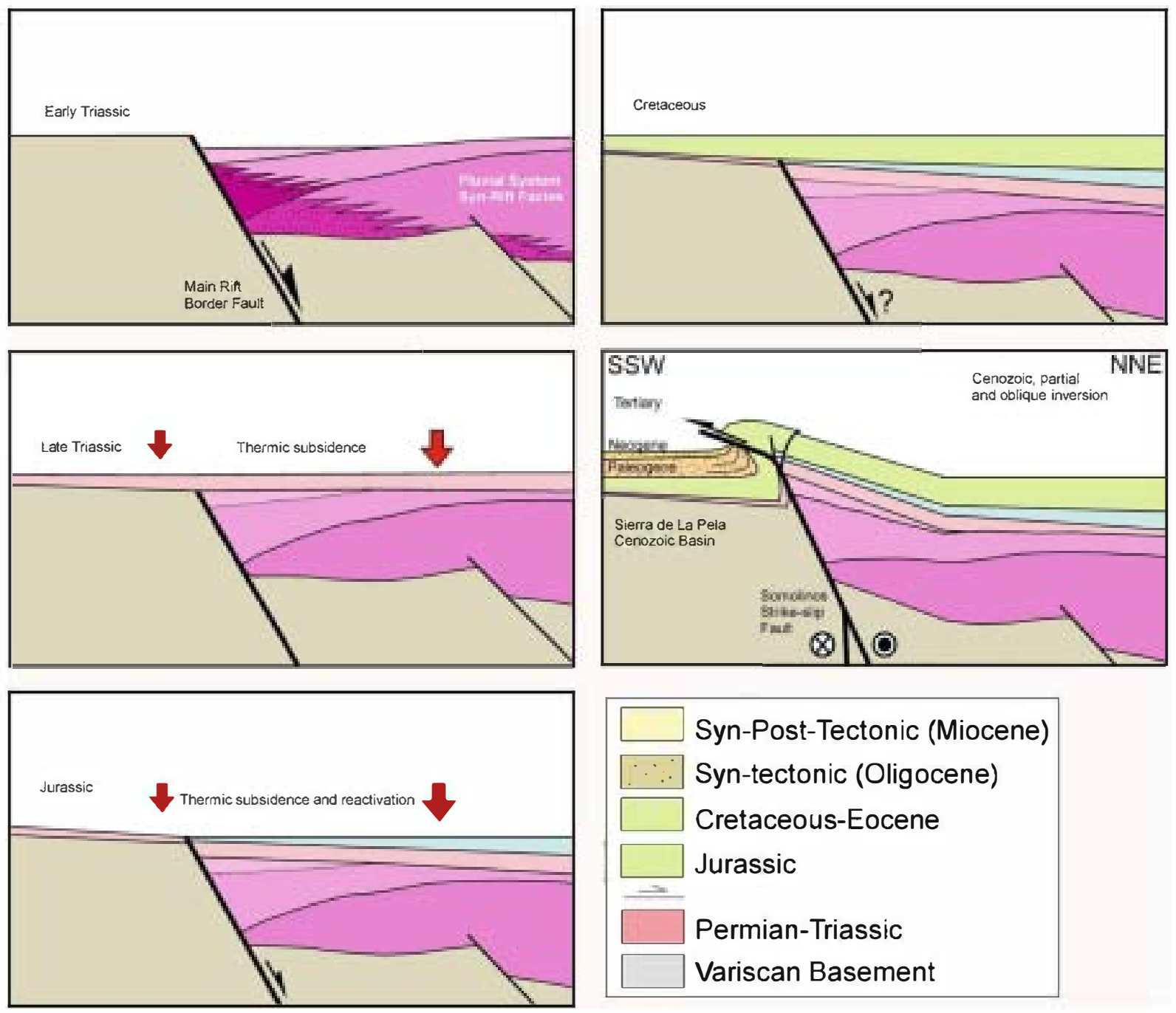

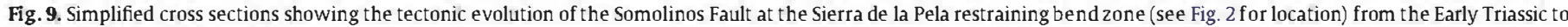
the Cenozoic partial inversion. 
strike-slip faults (Fig. 10B). Given the good outcrop quality, it is also an excellent place to observe where the Cenozoic deformation is being nucleated in relation to the rifting architecture (Fig. 11). In the Riba de Santiuste fold (Figs. $2(*), 10(3)$ and 11A,B) several conglomerate units deposited during the Permian-Triassic rifting show SE-directed paleocurrents in its southern, vertical flank, whereas in its northern limb, paleocurrents are N to NE directed (Sánchez-Moya et al., 1996; Sopeña and Sánchez-Moya, 1997). From the present-day en-echelon structure of the NW-SE strike-slip faults, it can be interpreted that the Cenozoic thrust and SE verging folds were nucleated on ancient relay ramps and accommodation zones of the normal rifting faults that mainly nucleated strike-slip movements during their inversion (Fig. 11C, D). Nucleation on NE-SW secondary faults related to the detailed structure of the relay ramps of the main NW-SE faults is also a possible explanation.

The southem border of this tectonic system close to the Central System can be followed southwards to the Huertapelayo restraining bend. In the footwall of this structure lies the Cenozoic Zaorejas Basin (Figs. 2 and 12). As a whole, this structural pattern indicates higher horizontal displacements, although the absence of reliable markers on either side of the fault system prevents a straightforward quantification of the cumulated displacement. This sub-unit is extended towards theSE in a narrow corridor which shows the strongest deformational features in the Castilian Branch: c) The Alto Tajo Fault System (Rodriguez-Pascua and De Vicente, 1998). In general, this system can be considered a popup flower stucture with rectilinear NW-SE folds along its trend, with sub-vertical axial surfaces and box-fold geometry. In some synclines Cenozoic sediments crop out defining NW-SE elongated basins. We interpret this group of structures as forced-like folds (bending folds) overlying NW-SE right lateral strike-slip faults, cored in the basement and involving the upper cover to different degrees. Although the structural mapping is complex, they can be clearly recognised as directional duplex and positive flower structures (Fig. 12A, B). Thrusting structures are also frequent at outcrop scale (Fig. 13).

Towards the N (Fig. 14), the massifs of Veredas, el Nevero and Albarracin form a series of restraining bends which accommodate most of the horizontal movement of the d) Corduente strike-slipreverse fault zone, through $\mathrm{E}-\mathrm{W}, \mathrm{N}$-verging thrusts. As a whole, this is a transpressive area with lower horizontal movement component than the one previously described.

The restraining bends are usually limited by smaller NNW-SSE left-lateral faults. These faults are Variscan discontinuities and normal second-order faults developed during the Triassic rifting, and reactivated during the Cenozoic contraction. The restraining bend of $\mathrm{El}$ Nevero originates the Piqueras Cenozoic basin in the footwall block, where simultaneous progressive unconformities can be seen on the thrust edge (E-W) and along the fault (NNW-SSE).

Northwards of this point, the e) Cubillejo reverse-strike-slip zone, limited by the Cubillejo Fault, almost mimics the Corduente fault zone, but with a stronger thrust component, with restraining bends in the massifs of the Paramera de Molina and Castellar. This sub-unit thrusts towards the $\mathrm{N}$ on a zone with relatively little deformation that separates the Almazán Basin from the Jiloca Basin. The NW branch of this basin has been affected by Plio-Quaternary extensional processes which mask the compressive structures (Fig. 14).

The f) Altomira Unit is very different from those mentioned above. This is a belt of thick skin folds and thrusts, in the E, and thin skin in the $\mathrm{W}$, whose tectonic transport ( $\mathrm{SW}$ to $\mathrm{W}$ ) and orientation of structures progressively change from $\mathrm{E}$ to $\mathrm{W}$. The Loranca Basin can be considered to be a piggyback basin of the westernmostthrusts of this unit up to the Early Miocene, as a result of some kind of tectonic escape towards the $W$ under constrictive conditions of deformation (Muñoz-Martín et al., 1998) under a generalised stress field with N-S compression (Fig. 2).At the SE end of this unit there are NW-SE folds, which are clearly linked to thrusts, which are sub-parallel to those of the Alto Tajo. Therefore, deformation partitioning could also occur (between strike-slip faults and thrusts) in structures with the same orientation.

\section{Cenozoic inversion: Paleostresses and strain partitioning}

The Cenozoic stress evolution of the Iberian Chain has been recently a matter of discussion and there is not a complete agreement

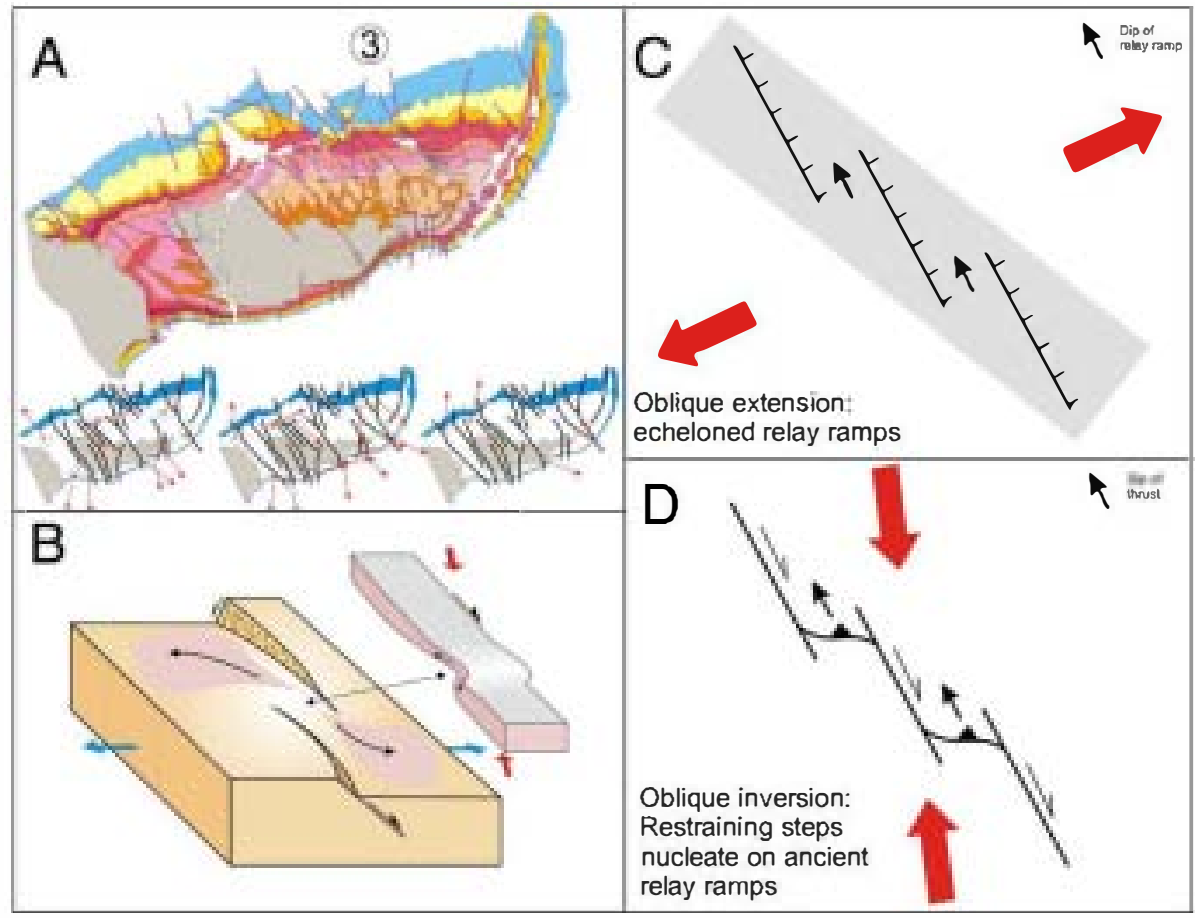

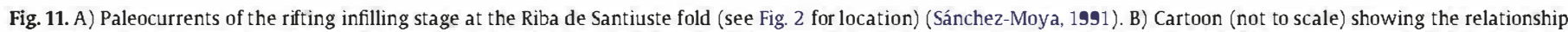

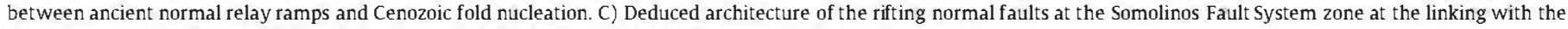
Central System (see Fig. 10). D) En-echelon Cenozoic folds can be a heritage of ancient echeloned relay ramps. 


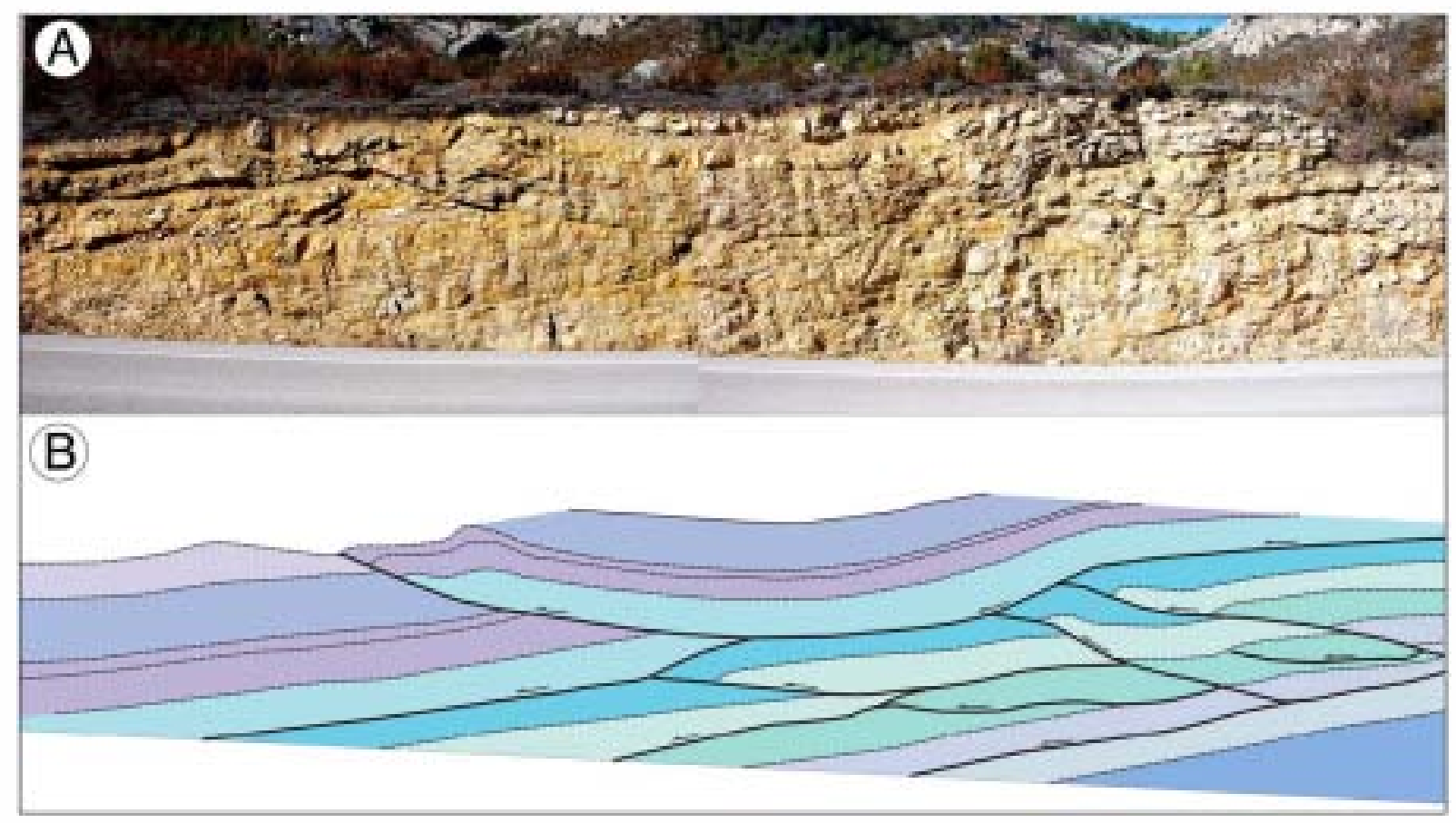

Fig. 13. A) Fault measurement site of Fig. 12C, B) Tectonic interpretation clearly related to thrusting.

age, ending with a late "pyrenean" field (NNE-SSW $s_{\text {hmax }}$ ) at the Middle Miocene.

Two main objections can be done to this analysis: a) The correlation between deduced tensorial solutions from fault population data sets and far field forces and tectonic events is not straightforward, since for example, there is no evidence of recent or active thrusting at the Pyrenees border and the position of the Alboran domain (Betics) during the Early Eocene is, at least, controversial. b) The filtering technique used for grouping the stress fields does not allow for large $S_{\text {hmax }}$ deviations. Nevertheless, constrictive strain can produce such deviations. Palinspastic reconstructions of plates point out to the existence of fan-shaped stress trajectories related to the Pyrenean collision that would produced a neutral stress point at the Iberia interior (De Vicente et al., 2005). Probably, the most important argument to support the constrictive conditions of the deformation is the tectonic escape towards the west of the Altomira Range with modelled stress deflections close to $90^{\circ}$ (Muñoz-Martín et al., 1998).

Paleo-stresses inversions from fault populations in the Alto Tajo Fault System sub-unit can be especially clarifying (Fig. 12C). They provide a majority of solutions with $S_{\text {hmax }}$ in a NE-SW direction ("Iberian" paleostress field, perpendicular to the main NW-SE direction of the chain). However, triaxial compression conditions, with two horizontal compressive axes, simultaneously activating reverse parallel faults oblique to the axes of folds are commonly found in sites located along NW-SE trending folds. In the example of fault population shown, 55\% of the data fit with a triaxial compression $(R=0.7)$ with a $N 170^{\circ} \mathrm{E} s_{\text {hmax }}$. Montecarlo-like analysis of this subpopulation indicate switch between $\sigma_{1}$ and $\sigma_{2}$ axes. Most of the rejected faults fit (24\% of the total data) with uniaxial compression $(R=0.3)$ with a similar $s_{\text {hmax }}\left(N 175^{\circ} \mathrm{E}\right)$, but in this case switching occurs between $\sigma_{3}$ and $\sigma_{2}$ axes (Fig. 12C). Evidently, and as a result of the very nature of inversion methods, a triaxial tensorial solution can be interpreted as the result of two independent uniaxial solutions by simply grouping (filtering) faults of similar trends. However, if we have a closer look to the macrostructures (Fig. 12A), the place of fault population measurement is located in the core of a very long and box anticline, with a straight hinge along a NE-SW direction. It is also remarkable that the structure of the deformed Jurassic limestone sequence where faults where measured, is clearly related to thrusting
(Fig. 13). This deformation style is not evident from the tectonic mapping (Fig. 12A), but it is in agreement with a regional $\mathrm{N}-\mathrm{S} \mathrm{shmax}_{\mathrm{hm}}$ as the one obtained from the inversion of fault data. Therefore, to explain the fault and fold pattern in this area, we can assume again, at least, two different folding events or just a single one, since $\mathrm{N}-\mathrm{S} s_{\text {hmax }}$ is clearly recorded in the NW-SE trending folds.

This interference of structures is very common throughout the Iberian Chain, with different chronological relationships between the different fold directions (Simón-Gómez, 1986; Andeweg et al., 1999). In our opinion, this is the result of a single process of strain partitioning under constrictive conditions of the deformation $\left(e_{x}=e_{y}>e_{z}\right)$, as recorded in Oligocene conglomerates of the Almazán Basin (CasasSainz and Maestro-González, 1996). In this situation, the earlier, first order structures would control and force the local, simultaneous occurrence of one or another type of paleostresses. The geometry of the rift, previous to the inversion, may lead to fold interference (and associated stresses) during the same tectonic event, as has been recognised in the Upper Atlas in a very close tectonic setting (Beauchamp, 2004).

The statis ally older activation of a NE-SW $s_{\text {hmax }}$ stress field can also be interpreted as an early strike-slip stage with the development of forced (bending) folds along the NW-SE right lateral faults, previously to the $\mathrm{E}-\mathrm{W}$ bends where main thrusting can occur slightly later.

Even though variations in the paleostress record through the sequence of syntectonic sedimentary units has also been defined, it is also remarkable that many of the intramountain basins-range contacts show progressive unconformities related both to the E-W reverse and the NW-SE strike-slip faults, that seem to be contemporary, as can be observed in the Piqueras, Zaorejas and Loranca Basins (Fig. 15). In any case, most of the Iberian Peninsula Cenozoic basins show general infilling trends that fit within a relatively simple and homogeneous pattern (Calvo et al., 1993; Calvo, 2004), with most stratigraphic ruptures concentrated during the Oligocene-Lower Miocene time span.

\section{Discussion and conclusions: Cenozoic Tectonic deformation model}

a) Triassic extensional episodes are associated with a wide rift geometry composed of many normal faults, that can indicate a 

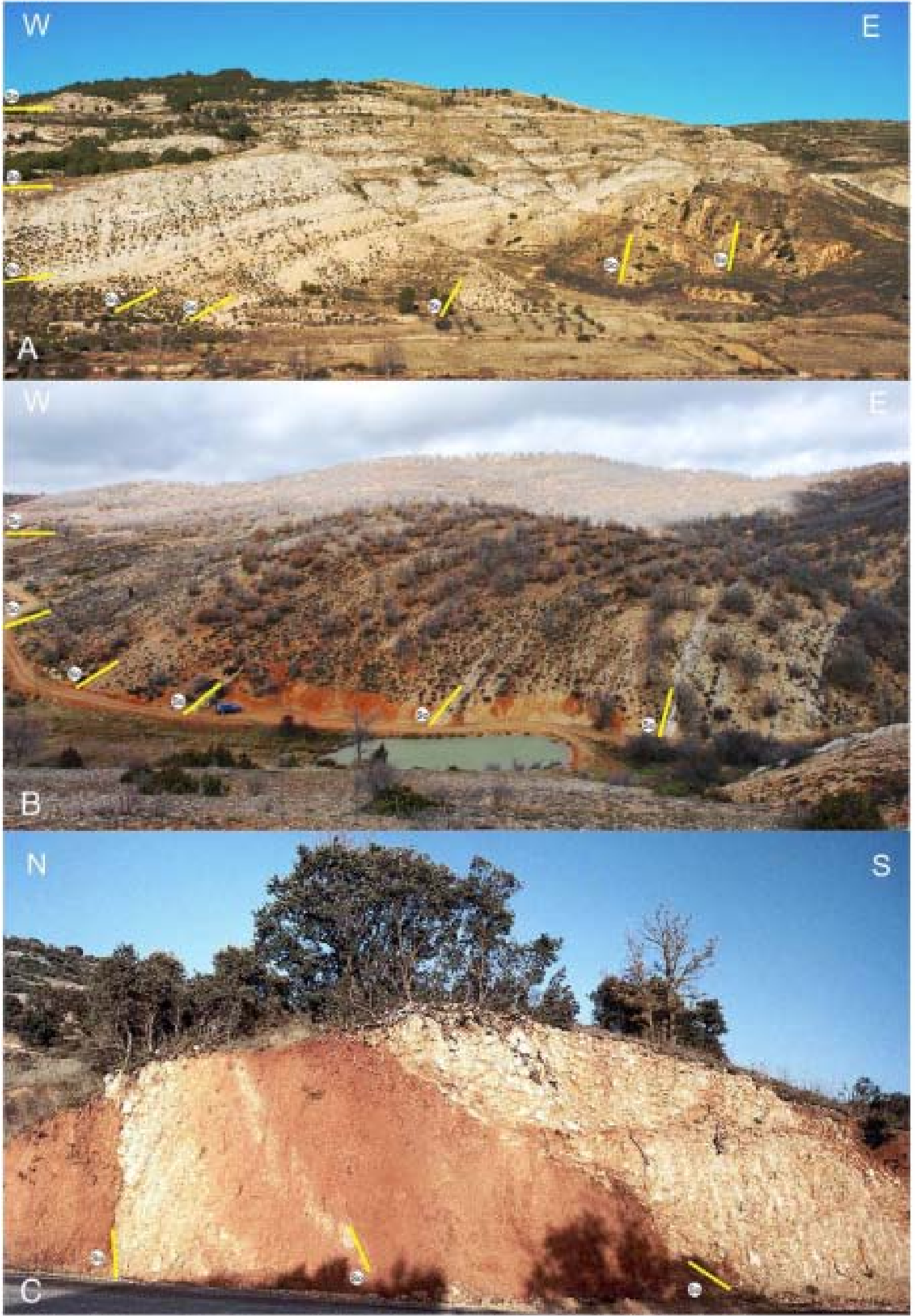

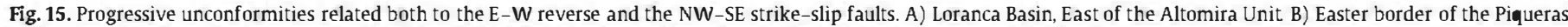
Basin, unconformity related to a strike-slip fault. C) $\mathrm{N}$ border of the Zaore jas Basin related to thrusting in a restraining bend 
c) The described macrostructural tectonic features can be explained through a generalised N-S shortening (Guimerà, 1988), but under constrictive conditions of deformation (De Vicente et al., 2005).

d) Under N-S convergence, E-W structures, including the CamerosDemanda thrust and the Utrillas-Montalban thrust (Casas-Sainz et al., 2000) best accommodate the tectonic deformation in the Aragonese branch of Iberian Chain. However, in the Castilian Branch, this was not the predominant structural grain previous to the Cenozoic deformations. Therefore, the result was an oblique inversion, where the previous main structures (normal NW-SE faults) acted as strike-slip faults.

e) Generally, thrust structures nucleate along relay ramps and areas of accommodation inherited since the Triassic Rift (De Vicente et al., 2007b). With an important horizontal movement component, the level of inversion along faults bordering Triassic Basins varies considerably, being in many places incomplete. This can be well observed in the Somolinos Fault where at its contact with the Central System, Triassic materials thrust over the Variscan basement, without recovering the previous (Mesozoic) normal throw, and the accumulation of syn-rift sediments to the $\mathrm{N}$ of the fault (Fig. 9).

f) Deformation by strike-slip faulting increases from $\mathrm{E}$ to $\mathrm{W}$ towards the Alto Tajo Fault System, with NW-SE forced folds. The Demanda-Cameros unit accommodates most part of the frontal $\mathrm{N}-\mathrm{S}$ shortening in the western part of the Iberian Chain. Probably, to the West, the two thrusts bounding the Central System to the North and south and to the East the Utrillas thrust (bounding to the South the Montalban Basin) are the responsible for most of the $\mathrm{N}-\mathrm{S}$ shortening. Conversely, in the relay area between these large thrusts strike-slip tectonics played an important role thus conditioning the geometry of inversion in the Castilian Branch. This is evident between the Cubillejo Fault and the Corduente Fault, where the restraining bends show E-W strikes within a general transpressive regime (Figs. 16 and 17).

g) Since two different folding trends (NE-SW to E-W and NW-SE) were simultaneously active, and generated within different mechanical behaviours (buckling and bending) we can also consider that a Cenozoic strain partitioning occurred (Fig. 17).

h) From paleostress analysis, both deformational mechanisms are undistinguishable; the first NE-SW paleostress field (Liesa and Simon-Gómez, 2007) can also be interpreted as an early strike-slip stage predating the development of thrusting in the restraining steps.

\section{Acknowledgements}

The study was supported by Consolider Ingenio 2006 "Topo Iberia” CSD2006-00041 and Spanish National Research Program CGL200613926-C02-01-02 “Topo Iberia Foreland" and CGL2006-01074. Gerardo de Vicente thanks to Prof. Antonio Teixell for pointing out some remarkable facts in the mapping of the Somolinos Fault.

\section{References}

Älvaro, M, Capote, R., Vegas, R., 1979. Un modelo de evolución geotectónica para la Cadena Celtibérica Acta Geologica Hispanica 14, 172-177.

Arche, A., López-Gómez, J., 1996. Origin of the Permian-Triassic Iberian Basin, centraleastern Spain. Tectonophysics 266, 443-464.

Arche, A., López-Gómez, J., Marzo, M., Vargas, H., 2004. The siliciclastic Permian-Triassic deposits in central and northeastern Iberian peninsula (Iberian, Ebro and Catalan Basins): a proposal for correlation. Geologica acta: A International Earth Science Journal 2 (004), 305-320.

Andeweg, B., De Vicente, G., Cloething, S., Giner, J.L., Muñoz Martín, A., 1999. Local stress fields and intraplate deformation of Iberia: variations in spatial and temporal interplay of regional stress sources. Tectonophysics 305, 153-164.

Beauchamp, W., 2004. Superposed folding resulting from inversion of a synrift accommodation zone, Atlas Mountains, Morocco. In: McClay, K.R. (Ed.), Thrust Tectonics and Hydrocarbon Systems. AAPG Memoir, vol. 82, pp. 635-646.

Bond, J., 1996. Tectono-sedimentary evolution of the Almazan basin, NE Spain In: Friend, P.F., Dabrio, C. J. (Eds), Tertiary Basins of Spain, vol. 6. Cambridge Univ. Press, pp. 203-213.
Calvo, J.P., Daams, R., Morales, J., López-Martínez, N., Agustí, J., Anadón, P., Armenteros, I. Cabrera, L., Civis, J., Corrochano, A., Diaz-Molina, M., Elízaga, E., Hoyos, M., Martín Suárez, E., Martínez, J., Moissenet, E., Muñoz, A., Pérez-García, P., Pérez-González, A., Portero, J.M., Robles, F., Santisteban, C. Torres, T., Van der Meulen, A.J., Vera, J. A. Mein, P., 1993. Up-to-date Spanish continental Neogene synthesis and paleoclimatic interpretation. Revista de la Sociedad GeoloÂgica de EspanÁ 6, 1-16.

Calvo, J.P., 2004. Rasgos comunes de las Cuencas cenozoicas. In: Vera, J.A. (Ed.), Geología de España. SGE, IGME, Madrid, pp. 584-586.

Campos, R., 1986. Estudio gravimétrico del Sector Central de la Cordillera Ibérica (Transversal Guadalajara-Zaragoza). Tesis de Licenciatura. Universidad Complutense de Madrid, $77 \mathrm{pp}$

Casas, A.M., Casas, A., Pérez, S., Tena, S., Barrier, L., Gapais, D., Nalpas, T., 2000. Syntectonic sedimentation and thrust-and-fold kinematics at the intra-mountain Montalbán Basin (northern Iberian Chain, Spain). GeodinamicaActa 1,1-17.

Casas-Sainz, A.M, Maestro-González, A., 1996. Deflection of a compressional field by large-scale basement faults. A case study from the Tertiary Almazán basin (Spain). Tectonophysics 9 (1-2), 51-66.

Casas-Sainz, A.M, Gil-Imaz, A., 1998. Extensional subsidence, contractional folding and thrust inversion of the eastern Cameros Basin, northern Spain. Geologische Rundschau $86(4), 802-818$

Casas-Sainz, A.M., Cortes-Gracia, A., Maestro-González, A., 2000. Intraplate deformation and basin formation during the Tertiary within the northern Iberian Plate; origin and evolution of the Almazán Basin. Tectonics 19 (2), 258-289.

Capote, R., Muñoz, J.A., Simón, J.L, Liesa, C.L., Arlegui, L.E., 2002. Alpine tectonics I: the Alpine system north of the Betic Cordillera In: Gibbons, W, Moreno, T (Eds), Geology of Spain. Geological Society, Iondon, pp. 385-397.

Cloetingh, S., Burov, E., Beelman, F., Andeweg, B. Andriessen, P.A.M, Garcia-Castellanos, D., DeVicente, G., Vegas, R, 2002. Lithospheric folding in Iberia. Tectonics 21 (5), 1041-1067.

De Vicente, G., 1988. Análisis poblacional de fallas. El sector de enlace Sistema CentralCordillera Ibérica. Ph Doctoral Thesis. Universidad Complutense de Madrid. 317 pp

De Vicente, G., Muñoz Martín, A., Vegas, R., Cloetingh, S., Casas, A., González Casado, J. M., Âlvarez, J., 2005. Neutral points and constrictive deformation in paleostresses analysis: the Cenozoic contraction of Iberia. Geophysical Research Abstracts Vol 7 , 04272.

De Vicente, G., Vegas, R., Muñoz-Martín, A., Silva, P.G., Andriessen, P., Cloetingh, S., González-Casado, J.M., Van Wees, J.D., Álvarez, J., Carbó, A., Olaiz, A., 2007a Cenozoic thick-skinned and topography evolution of the Spanish Central System Global and Planetary Change 58, 335-381

De Vicente, G., Muñoz-Martín, A., Sopeña, A., Sánchez-Moya, Y., Vegas, R, Fernández Iozano, J., Olaiz, A., De Vicente, R., 2007b. Oblique Strain Partitioning and Transpression on a Partially Inverted Rift: the Castilian Branch of Iberian Chain 3rd International Topo-Europe Workshop, Rome

De Vicente, G., Vegas, R, in press. Topography Controlled by Iarge Scale Distributed Deformation Along the Western Africa-Eurasia Limit: Tectonic Constrains Tectonophysics.

Guimerà, J, 1988 Estudi estructural de l'enllaç entre la Serralada Iberica y la Serralada Costanera Catalana Ph Doctoral Thesis, Univ. de Barcelona: $600 \mathrm{pp}$.

Guimerà, J., 2004. Cadenas con cobertera: Las Cadenas Ibérica y Costera Catalana In: Vera, J.A. (Ed.), Geología de España. SGE-IGME, Madrid

Guimerà, J, Más, R., Alonso, A., 2004. Intraplate deformation in the NW Iberian Chain: Mesozoic extension and contractional inversion. Journal of the Geological Society (Iondon) 16, 291-303.

Lago, M, Arranz, E., Galé, C, 2002. Stephanian-Permian volcanism of the Iberian Ranges and Atienza. In: Gibbons, W., Moreno, T. (Eds), The Geology of Spain Geological Society, Iondon, pp. 126-128.

Lago, M., Arranz, E., Gil, A., Pocovi, A., 2004. In: Vera, J.A. (Ed.), Cordilleras Ibérica y Costero-Catalana; Magmatismo asociado. Geología de España SGE-IGME, Madrid

Liesa, C.L. (2000): Fracturación y campos de esfuerzos compresivos alpinos en la Cordillera Ibérica y el NE peninsular. Tesis Doctoral, Univ. de Zaragoza, 611 pp.

Liesa, C., Simón-Gómez, J.L, 2007. A probabilistic approach for identifying independent remote compressions in an intraplate region: The Iberian Chain (Spain). Math Geology 39,337-348.

Muñoz-Martín, A., Cloetingh, S., De Vicente, G., Andeweg, B., 1998. Finite-element modelling of Tertiary paleostress fields in the eastern part of the Tajo Basin. Tectonophysics 300, 47-62.

Muñoz-Martín, Álvarez, J., Carbó, A., de Vicente, Vegas, R, Cloetingh, S., 2004. La estructura de la corteza del Antepaís Ibérico. In: Vera, J.A. (Ed.), Geología de España. SGE-IGME, Madrid.

Pulgar, J.A., Gallart, J., Fernández-Viejo, G., Pérez-Estaún, A., Alvarez-Marrón, J., ESCIN Group, 1996. Seismic image of the Cantabrian Mountains uplift in the western extension of the Pyrenean Belt from integrated ESCIN reflection and refraction data Tectonophysics $262 \mathrm{~A}$

Querol, R, 1989. Geología del Subsuelo de la Cuenca del Tajo. Instituto Tecnológico Geominero de España, Madrid

Ramos, A., Sopeña, A., Pérez-Arlucea, M, 1986. Evolution of Buntsandstein fluvial sedimentation in the northwest Iberian Ranges (Central Spain). Journal of Sedimentary Petrology 56, 862-875.

Ramos, A., Sopeña, A., Sánchez-Moya, Y., Muñoz, A., 1996. Subsidence analysis, maturity modelling and hydrocarbon generation of the Alpine sedimentary sequence in the NW of the Iberian Ranges (Central Spain). Cuadernos de Geología Iberíca 21, 23-53.

Rey-Moral, C., Gómez-Ortiz, D., Sánchez-Serrano, F., Tejero-López, R., 2004. Modelos de densidades de la corteza de la cuenca de Almazán (Provincia de Soria). Boletín Geológico y Minero 115 (1), 137-152.

Rodríguez-Pascua, M.A., De Vicente, G., 1998 Análisis de paleoesfuerzos en cantos de depósitos conglomeráticos terciarios de la cuenca de Zaorejas (rama castellana de la Cordillera Ibérica). Revista de la Sociedad GeoloÂgica de Espana 11, 169-180. 
Sadiford, M., Frederiksen, S., Braun, J., 2003. The long-term thermal consequences of rifting: implications for basin reactivation. Basin Research 15, 23-43.

Salas, R., Guimerá, J., 1997. Estructura y estratigrafia secuencial de la cuenca del Maestrazgo durante la etapa de rift jurasica superior-cretacica inferior (Cordillera Iberica oriental). Structure and sequential stratigraphy of the Maestrazgo Basin during the Upper Jurassic-Lower Cretaceous rift stage, eastern Iberian Mountains. Boletín Geológico y Minero 108 (4-5), 393-402.

Sánchez-Moya, Y, 1991. Evolución sedimentológica y controles estructurales de un borde de cuenca extensional: Comienzo de la sedimentación del Mesozoico en un sector del margen occidental de la Cordillera Ibérica. Colección Tesis Doctorales U.C.M. 232 (92), 443 pp.

Sánchez Moya, Y., Sopeña, A., Ramos, A., 1996. Infill architecture of a non-marine halfgraben Triassic basin (central Spain). Journal of Sedimentary Research 66, 1122-1136.

Simancas, J.F., Carbonell, R, Gonzalez Lodeiro, F., Pérez Estaún, A., Juhlin, C., Ayarza, P., Kashubin, A, Azor, A., Martínez Poyatos, D., Almodóvar, G.R., Pascual, E., Sáez, R, Expósito, I., 2003. The crustal structure of the transpressional Variscan Orogen of the SW Iberia: The IBERSEIS Deep Seismic Reflection Profile. Tectonics 22 (6), $1062-1082$

Simón-Gómez, J.L., 1986. Analysis of a gradual change in stress regime (example from eastern Iberian Chain, Spain). Tectonophysics 124, 37-53.

Sopeña, A., 1979. Estratigrafía del Pérmico y Triásico del noroeste de la Provincia de Guadalajara. Permian and Triassic stratigraphy of northwestern Guadalajara Seminarios de Estratigrafía 5329 pp.

Sopeña, A., 2004. Cordillera Ibérica y Costero Catalana. In: Vera, J.A. (Ed.), Geología de España. SGE-IGME, Madrid, pp. 465-527.

Sopeña, A., Sánchez-Moya, Y., 1997. Tectonic systems tract and depositional architecture of western border of the Triassic Iberian Trough, Central Spain. Sedimentary Geology 113, 245-267.
Suriñach, E Vegas, $R$, 1988 Jateral inhomogeneities of the Hercynian crust in central Spain. Physics of the Earth and Planetary Interiors 51, 226-234

Teixell, A., Arboleya, M.L., Julivert, M., y Charroud, M., 2003. Tectonic shortening and topography in the central High Atlas (Morocco). Tectonics 22 (5), 1051-1071.

Tirel, C, Brun, J.P., Sokoutis, D., 2006. Extension of thickened and hot lithospheres: Inferences from laboratory modeling. Tectonics 25. doi:10.1029/2005TC001804 TC1005.

Van Wees, J.D., Cloetingh, S., 1996. 3D flexure and intraplate compression in the North Sea Basin. Tectonophysics 266, 243-359.

Van Wees, J.D., Beekman, F., 2000. Lithosphere rheology during intraplate basin extension and inversion. Inferences from automated modeling of four basins in Western Europe. Tectonophysics 320, 219-242.

Van Wees, J.D., Arche, A., Beijdorff, C.G., Lopez-Gomez, J., Cloetingh, S., 1998. Temporal and spatial variations in tectonic subsidence in the Iberian Basin (E Spain). Tectonphysics 300, 285-310.

Vegas, R., De Vicente, G., Muñoz Martín, A., Olaiz, A., Palencia, A. Osete, M.L. 2005. Was the Iberian Plate moored to Africa during the Tertiary? Geophysical Research Abstracts, Vol 7, 06769.

Vegas, R., 2006. Modelo tectónico de formación de los relieves montañosos y las cuencasde sedimentación terciarias del interior de la Península Ibérica. BoletiẤn de la Real Sociedad EspanÁola de Historia Natural (Sec Geol) (1-4), 31-40.

Ziegler, P.A., Cloetingh, S., 2004. Dynamic processes controlling evolution of rifted basins. Earth-Science Reviews 64, 1-45. 